\title{
Effect of Potassium and Nitrogen Fertilizer on Switchgrass Productivity and Nutrient Removal Rates under Two Harvest Systems on a Low Potassium Soil
}

\author{
Maru K. Kering • Twain J. Butler • Jon T. Biermacher • \\ Jagadeesh Mosali • John A. Guretzky \\ Published online: 5 October 2012 \\ (C) The Author(s) 2012. This article is published with open access at Springerlink.com
}

\begin{abstract}
Biomass demand for energy will lead to utilization of marginal, low fertility soil. Application of fertilizer to such soil may increase switchgrass (Panicum virgatum L.) biomass production. In this three-way factorial field experiment, biomass yield response to potassium (K) fertilizer ( 0 and $68 \mathrm{kgK}$ $\mathrm{ha}^{-1}$ ) on nitrogen $(\mathrm{N})$-sufficient and $\mathrm{N}$-deficient switchgrass $\left(0\right.$ and $\left.135 \mathrm{kgNha}^{-1}\right)$ was evaluated under two harvest systems. Harvest system included harvesting once per year after frost (December) and twice per year in summer (July) at boot stage and subsequent regrowth after frost. Under the one-cut system, there was no response to $\mathrm{N}$ or K only $\left(13.4 \mathrm{Mgha}^{-1}\right)$ compared to no fertilizer $\left(12.4 \mathrm{Mgha}^{-1}\right)$. Switchgrass receiving both $\mathrm{N}$ and $\mathrm{K}\left(14.6 \mathrm{Mgha}^{-1}\right)$ produced $18 \%$ greater dry matter (DM) yield compared to no fertilizer check. Under the two-cut harvest system, $\mathrm{N}$ only $\left(16.0 \mathrm{Mgha}^{-1}\right)$ or $\mathrm{K}$ only $\left(14.1 \mathrm{Mgha}^{-1}\right.$ ) fertilizer produced similar DM to no fertilizer $\left(15.1 \mathrm{Mgha}^{-1}\right)$. Switchgrass receiving both $\mathrm{N}$ and $\mathrm{K}$ in the two-cut system $\left(19.2 \mathrm{Mgha}^{-1}\right)$ produced the greatest $(P<$ $0.05) \mathrm{DM}$ yield, which was $32 \%$ greater than switchgrass receiving both $\mathrm{N}$ and $\mathrm{K}$ in the one-cut system. Nutrient removal (biomass $\times$ nutrient concentration) was greatest in plots receiving both $\mathrm{N}$ and $\mathrm{K}$, and the two-cut system had greater nutrient removal than the one-cut system. Based on these results, harvesting only once during winter months reduces nutrient removal in harvested biomass and requires less inorganic fertilizer for sustained yields from year to year compared to two-cut system.
\end{abstract}

\footnotetext{
M. K. Kering · T. J. Butler $(\bowtie) \cdot J$. T. Biermacher $\cdot$ J. Mosali

The Samuel Roberts Noble Foundation,

2510 Sam Noble Parkway,

Ardmore, OK 73401, USA

e-mail: tjbutler@noble.org

J. A. Guretzky

Department of Agronomy and Horticulture, University

of Nebraska-Lincoln,

310 Keim Hall,

Lincoln, NE 68583, USA
}

Keywords Switchgrass biomass yield · Nitrogen · Potassium $\cdot$ Harvest management

\section{Introduction}

Current and future increase in demand for bioenergy crops may lead to utilization of marginal low fertility soils for switchgrass production. Early screening studies facilitated by the US Department of Energy identified switchgrass as having potential for production as a bioenergy crop [1]. Subsequent research looked into variety development, regional adaptations, and management strategies to improve switchgrass productivity [2]. While switchgrass has adaptive traits that allow it to grow in marginal areas with low soil fertility $[2,3]$, its economic productivity may be improved with better fertilizer management strategies. Several studies have reported positive responses to nitrogen $(\mathrm{N})$ fertilizer by switchgrass produced for bioenergy [4-7], and responses to phosphorus $(\mathrm{P})$ fertilization by switchgrass for both forage and bioenergy [8-13] have been reported. Response data of switchgrass to potassium $(\mathrm{K})$ fertilization is limited, especially on low fertility soils, where switchgrass is most likely to be grown for bioenergy purposes.

Potassium, a critical element involved in enzyme activation, protein synthesis, stomatal regulation, plant-water relations, and cation-anion balance in the plant [14] can affect crop growth when it is deficient. While optimal crop growth may be possible in high fertility soils, application of $\mathrm{K}$ fertilizers to areas with low inherent soil $\mathrm{K}$ may be needed for increased biomass yield. Potassium fertilization has been reported to increase water- and N-use efficiency in warmseason cereals like pearl millet [Pennisetum americanum (L.) Leeke] and sorghum (Sorghum bicolor L.) and forage yields in warm-season forages like bermudagrass (Cynodon dactylon Pers.) $[15,16]$. In fact, bermudagrass yield per unit of $\mathrm{N}$ dropped from 42 to $36 \mathrm{~kg}$ in absence of $\mathrm{K}$ fertilizer; $\mathrm{K}$ 
fertilizer increased total yield by $12 \%$ [17]. At two Kdeficient sites in eastern Texas, application of $\mathrm{K}$ at rates up to $278 \mathrm{kgK} \mathrm{ha}{ }^{-1}$ increased "Coastal" bermudagrass forage yield by between 10 and $71 \%$ [18]. Unlike forage and grain crops whose fertilizer requirements have been well documented, there is limited information on $\mathrm{K}$ requirements for switchgrass biomass production, and data available have been contradictory and mostly from greenhouse experiments. In one study, biomass yield of switchgrass harvested at anthesis showed no response to $\mathrm{K}$ fertilizer despite a twofold increase in tissue $\mathrm{K}$ concentration [19]. In another study, switchgrass receiving either $\mathrm{N}$ and $\mathrm{P}$ or $\mathrm{N}, \mathrm{P}$, and $\mathrm{K}$ fertilizer produced greater biomass than switchgrass receiving $\mathrm{N}$ fertilizer alone [9]. Despite the critical roles of $\mathrm{K}$ in plant growth and function, few studies have examined $\mathrm{K}$ fertilizer requirements of switchgrass for bioenergy biomass production.

Management factors that may affect switchgrass requirements for $\mathrm{K}$ are harvest timing and frequency. Harvesting biomass after plant senescence allows nutrients to be remobilized to belowground structures, thereby reducing nutrient concentrations and removal rates $[4,7,13,20,21]$. While several reports have pointed out that one-cut per year harvests produce near maximum switchgrass biomass yields [4-6], others have reported significant increases in biomass yield with a two-cut per year system [7, 22]. Several of these studies delayed harvest of switchgrass until after a killing frost to allow the crop to fully senesce and reduce biomass nutrient concentration even further. Despite the potential for greater switchgrass yield with multiple harvests per year, excessive removal of nutrients during early- to mid-summer harvests [7, 22, 23] could result in nutrient mining and deplete inherent soil fertility over time. Increased removal of nutrients has been observed in warm-season grasses harvested multiple times during the growing season. For example in coastal bermudagrass, biomass yield responses to $\mathrm{K}$ fertilization were not observed in first and second cuttings but were observed in third and forth cuttings as a result of soil $\mathrm{K}$ depletion from earlier cuts [18]. At a fertilization rate of $278 \mathrm{kgKha}^{-1}$, soil exchange $\mathrm{K}$ levels at 0 to15-cm depths after 3 years of bermudagrass production were reduced to levels below those found at project initiation [18]. By harvesting biomass in post-frost periods, nutrients like $\mathrm{K}$ may be leached out of senesced plant material [24] and returned to the soil, reducing K removal in biomass. Previous studies have reported $\mathrm{K}$ concentrations as low as $0.60 \mathrm{~g} \mathrm{~kg}^{-1} \mathrm{DM}$ in switchgrass harvested the following spring, values more than $80 \%$ lower than that of switchgrass harvested in autumn [25, 26].

Increased removal of nutrients by harvesting multiple times per year and possible reductions in soil fertility may increase fertilizer requirements of bioenergy crops in the future. Therefore, harvest frequency and timing are critical factors in development of fertilizer programs for long-term production of switchgrass for bioenergy [27]. Monti et al. [27] compared two-cut and one-cut system and found that the twocut system produced greater biomass during the first two seasons, but reduced switchgrass vigor and productivity the following two seasons. Because of the paucity of information on $\mathrm{K}$ fertilizer on switchgrass biomass and nutrient removal, an experiment was carried out with the objective of evaluating the effects of harvest system and $\mathrm{K}$ fertilizer rate on biomass yield and nutrient removal rates of switchgrass under no-N fertilizer or adequate $\left(135 \mathrm{kgNha}^{-1}\right) \mathrm{N}$ fertilizer level.

\section{Materials and Methods}

Research was conducted at the Noble Foundation Pasture Demonstration Farm in Carter County (34 $22^{\prime} \mathrm{N}$; $97^{\circ} 21^{\prime}$ W) near Ardmore, Oklahoma from 2008 to 2011. The experiment was a randomized complete block design with a factorial arrangement of treatments and four replications. Treatments consisted of two harvest systems, two $\mathrm{N}$ fertilizer rates, and two $\mathrm{K}$ fertilizer rates. Harvest systems included harvesting once per year after killing frost (December) or twice per year, first cut at boot stage (July) and the regrowth after killing frost. Nitrogen fertilizer (46-0-0) was applied at 0 or $135 \mathrm{kgNha}^{-1}$ and $\mathrm{K}$ fertilizer (0-0-60) was applied at 0 or $68 \mathrm{kgK}_{2} \mathrm{Oha}^{-1}$ in order that neither $\mathrm{N}$ or $\mathrm{K}$ would be limiting for switchgrass growth based on recommended fertilizer rates [28]. Treatments were applied to a 1-yearold stand of "Alamo" switchgrass planted at $4.5 \mathrm{~kg}$ pure live seed per hectare using a Brillion (Brillion, WI, USA) broadcaster seeder in early May 2007. The soil at the site was a Chickasha loam (fine loamy, mixed, active, thermic Udic Argiustolls) and at the $0-15 \mathrm{~cm}$ depth had the following characteristics at project initiation: pH6.1, $2.2 \%$ organic matter, $\mathrm{NO}_{3}-\mathrm{N}$ (9 $\mathrm{mg} \mathrm{kg}^{-1}$ soil), $\mathrm{P}\left(44 \mathrm{mgkg}^{-1}\right.$ soil, Mehlich III), K (88 $\mathrm{mgkg}^{-1}$ soil, Mehlich III), Ca (733 $\mathrm{mgkg}^{-1}$ soil), $\mathrm{Mg}$ (282 $\mathrm{mgkg}^{-1}$ soil), and $\mathrm{Na}\left(23 \mathrm{mgkg}^{-1}\right.$ soil). Phosphorus fertilizer was not applied to the experimental plots because the soil test $\mathrm{P}$ level was considered sufficient for native warm-season grass production in Oklahoma [28]. Potassium treatments were applied beginning in 2007 and $\mathrm{N}$ fertilizer treatments beginning in 2008. During the establishment year of 2007, $1.1 \mathrm{kgaiha}^{-1}$ 2, 4-D amine 2, 4dichlorophenoxyacetic acid (Weedar 64) was applied after the five-leaf stage of switchgrass to control broadleaf weeds.

Biomass harvest dates at boot stage occurred on 7, 15, 19, and 8 July, while the harvest dates after killing frost occurred on 17, 11, 17, and 9 December of 2008, 2009, 2010, and 2011, respectively. Biomass was harvested with either a Carter (Brookston, IN, USA) forage harvester or a HEGE (Colwich, KS, USA) forage plot harvester at a 10-cm stubble height. Subsamples of the harvested biomass were collected for DM determination and nutrient analysis. 
Following drying at $60{ }^{\circ} \mathrm{C}$, samples were ground to pass a $<1 \mathrm{~mm}$ screen using a Wiley Mill (Thomas Scientific, Swedesboro, NJ, USA) and prepared for nutrient analysis. Nutrient concentrations were estimated with near-infrared spectroscopy (NIRS) analysis using equations developed by the NIRS Forage and Feed Testing Consortium (Table 2) and included DM, N, P, K, Ca, and Mg. The amount of nutrient removed annually in the two-cut harvest system was calculated using total annual biomass yield and mean nutrient concentration from both harvest periods. In the one-cut system, nutrient removal was calculated using the biomass yield after frost and nutrient concentration at time of harvest.

Average nutrient concentration in biomass material for the two-cut system was calculated as a weighted average, $X_{a}=\left[\left(X_{s} \times Y_{s}\right)+\left(X_{w} \times Y_{w}\right)\right] /\left(Y_{s}+Y_{w}\right)$, where $X_{a}=$ average nutrient concentration (grams per kilogram), $X_{s}=$ nutrient concentration (grams per kilogram) in summerharvested biomass, $X_{w}=$ nutrient concentration (grams per kilogram) in winter (regrowth) harvested biomass, $Y_{s}=$ yield (kilograms) of summer harvested biomass, and $Y_{w}=$ yield (kilograms) of winter (regrowth) harvested biomass.

Analysis of variance was conducted using the mixed models procedure in SAS to determine main effects and interactions of harvest system, $\mathrm{K}$ and $\mathrm{N}$ fertilizer rate on total annual biomass, nutrient concentration, and nutrient removal rates. Harvest system, $\mathrm{K}$ and $\mathrm{N}$ fertilizer rate were considered fixed effects, and years and replications were considered random effects in the analyses. Year was considered a repeated measure for biomass and nutrient removal rates. The statistical models applied the autoregressive (AR1) spatial power covariance structure to account for temporal autocorrelation in data collected across growing periods. Independent analysis was done for summer harvest to determine the effect of fertilizer application on summer yield and nutrient concentration and removal.

\section{Results}

Precipitation during the four production years varied (Fig. 1). Long-term (30 years) annual rainfall at the site was $967 \mathrm{~mm}$. Total annual precipitation was greater than the long-term average in $2009(1,142 \mathrm{~mm})$ and less than the long-term average in 2008 (652 $\mathrm{mm}), 2010(870 \mathrm{~mm})$, and $2011(565 \mathrm{~mm})$. Precipitation amounts were especially great in the spring and late summer to early autumn of 2009 (Fig. 1). June and July of 2011 had the least rainfall with only $14 \mathrm{~mm}$ compared to long-term average of $171 \mathrm{~mm}$ for the same months. Temperatures were comparable to the long-term average for all years except the summer of 2011. This period was the driest and hottest with temperatures being $2-3{ }^{\circ} \mathrm{C}$ higher than in other years (data not shown).

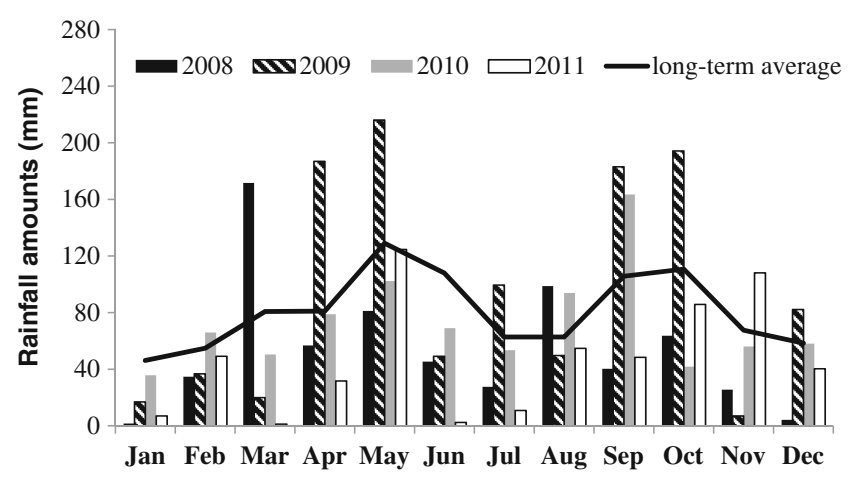

Fig. 1 Mean monthly precipitation from 2008 through 2011 and the long-term (30 years) average at the Noble Foundation Pasture Demonstration Farm, Ardmore, OK

\section{Biomass Yield}

Switchgrass harvested in the two-cut system generally produced greater biomass (20\% on average) compared to the one-cut system. However, harvest system by $\mathrm{N}$ fertilizer, $\mathrm{K}$ by $\mathrm{N}$ fertilizer, and three-way interaction had significant $(P<0.02)$ effects on biomass, therefore means are reported by harvest system and fertilizer treatment (Table 1).

\section{One-Cut System}

Total biomass was affected $(P<0.01)$ by $\mathrm{N}$ and $\mathrm{K}$ rate interaction. In the one-cut system, switchgrass receiving $\mathrm{K}$ and $\mathrm{N}$ fertilizer $\left(14.6 \mathrm{Mgha}^{-1}\right)$ produced $18 \%$ greater $(P<$ $0.05)$ biomass than control plots receiving no fertilizer (12.4 $\mathrm{Mgha}^{-1}$ ); however, plots receiving $\mathrm{N}$ only or $\mathrm{K}$ only did not differ from the untreated control plots receiving no inorganic fertilizer.

Table 1 Switchgrass biomass yield (megagram per hectare) as affected by harvest system, $\mathrm{N}$ and $\mathrm{K}$ fertilizer application rate during four production years

\begin{tabular}{|c|c|c|c|c|c|}
\hline \multirow{2}{*}{$\begin{array}{l}\text { Harvest } \\
\text { system }\end{array}$} & \multirow[t]{2}{*}{$\mathrm{N}$ rate } & \multirow[t]{2}{*}{$\mathrm{K}$ rate } & \multicolumn{2}{|c|}{ Harvest time } & \multirow[t]{2}{*}{ Total yield $\left(\mathrm{Mgha}^{-1}\right)$} \\
\hline & & & $\begin{array}{l}\text { Boot stage } \\
\text { Summer }\end{array}$ & $\begin{array}{l}\text { After frost } \\
\text { Winter }\end{array}$ & \\
\hline \multirow[t]{4}{*}{ One cut } & 0 & 0 & & 12.4 & 12.4 \\
\hline & 0 & 68 & & 13.4 & 13.4 \\
\hline & 135 & 0 & & 13.4 & 13.4 \\
\hline & 135 & 68 & & 14.6 & 14.6 \\
\hline \multirow[t]{4}{*}{ Two cuts } & 0 & 0 & 11.5 & 3.6 & 15.1 \\
\hline & 0 & 68 & 10.4 & 3.7 & 14.1 \\
\hline & 135 & 0 & 12.2 & 3.8 & 16.0 \\
\hline & 135 & 68 & 14.5 & 4.7 & 19.2 \\
\hline $\operatorname{LSD}_{(0.05)}$ & & & 1.5 & $0.5^{\mathrm{a}}$ & 1.5 \\
\hline
\end{tabular}

${ }^{\mathrm{a}} \mathrm{LSD}$ is for regrowth biomass comparison only 


\section{Two-Cut System}

During the boot stage harvest (summer), $\mathrm{N}$ rate by $\mathrm{K}$ rate interaction $(P<0.02)$ affected biomass yield while fertilizer treatment had no effect on regrowth yield. In the two-cut system, the boot stage harvest provided $75 \%$ of the total switchgrass biomass. During the boot stage harvest for the two-cut system, switchgrass plots receiving both $\mathrm{N}$ and $\mathrm{K}$ produced the greatest biomass, which was $26 \%$ greater than the untreated (no fertilizer) check, $19 \%$ greater than the Nonly treatment, and $39 \%$ greater than the $\mathrm{K}$-only treatment. Total biomass was also affected $(P<0.01)$ by $\mathrm{K}$ and $\mathrm{N}$ rate interaction. Switchgrass plots receiving both $\mathrm{N}$ and $\mathrm{K}$ produced the greatest total biomass, which was $27 \%$ greater than the no fertilizer check, $20 \%$ greater than the N-only treatment, and $36 \%$ greater than the K-only treatment.

\section{Nutrient Concentrations in Harvested Biomass}

Harvest timing by $\mathrm{N}$ fertilizer by $\mathrm{K}$ fertilizer treatment interactions affected nutrient concentrations $(\mathrm{N}, \mathrm{P}, \mathrm{K}, \mathrm{Ca}$, and $\mathrm{Mg}$ ); therefore, nutrient concentration means are reported by harvest system.

\section{One-Cut System}

The concentrations of $\mathrm{N}, \mathrm{P}, \mathrm{K}, \mathrm{Ca}$, and $\mathrm{Mg}$ for the one-cut harvest system were $8.3,1.01,2.7,2.9$, and $3.5 \mathrm{~g} \mathrm{~kg}^{-1}$, respectively (Table 2 ). The one-cut system harvested after frost had 27, 31, and $76 \%$ lesser concentrations of N, P, and $\mathrm{K}$, respectively, than biomass harvested in the two-cut system. In the one-cut harvest system, $\mathrm{K}$ application did not affect nutrient concentrations in the biomass. However, across $\mathrm{K}$ fertilizer rates, $\mathrm{N}$ fertilizer increased $\mathrm{N}(27 \%), \mathrm{P}$ (16\%), $\mathrm{Mg}(17 \%)$ from 7.3, 0.93 and $3.2 \mathrm{~g} \mathrm{~kg}^{-1}$ to 9.3 , 1.08 , and $3.7 \mathrm{~g} \mathrm{~kg}^{-1}$, respectively.

\section{Two-Cut System}

The concentrations of $\mathrm{N}, \mathrm{P}, \mathrm{K}, \mathrm{Ca}$, and $\mathrm{Mg}$ for two-cut harvest system averaged $11.4,1.5,10.9,4.1$, and $3.8 \mathrm{gkg}^{-1}$, respectively (Table 2). Regrowth biomass had $26 \%$ greater $\mathrm{N}$ $\left(13.6 \mathrm{~g} \mathrm{~kg}^{-1}\right), 46 \%$ less $\mathrm{P}\left(1.02 \mathrm{gkg}^{-1}\right)$, and $73 \%$ less $\mathrm{K}$ (3.5 $\left.\mathrm{g} \mathrm{kg}^{-1}\right)$ compared to boot stage harvest in summer (Table 2). During boot stage harvest in summer and the regrowth harvest after frost, switchgrass receiving both $\mathrm{N}$ and $\mathrm{K}$ fertilizer had greater $\mathrm{N}, \mathrm{P}, \mathrm{K}$, and $\mathrm{Mg}$ than switchgrass in the
Table 2 Mean nutrient concentration in switchgrass biomass under one- and two-cut systems as affected by $\mathrm{K}$ and $\mathrm{N}$ fertilizer application rate and harvest system
${ }^{a}$ Values are mean nutrient concentration calculated as weighted average for the two-cut system

\begin{tabular}{|c|c|c|c|c|c|c|c|}
\hline \multirow[t]{2}{*}{ Harvest system } & \multirow[t]{2}{*}{$\mathrm{N}$ rate } & \multirow[t]{2}{*}{$\mathrm{K}$ rate } & \multicolumn{5}{|c|}{ Nutrient concentration $\left(\mathrm{gkg}^{-1}\right)$} \\
\hline & & & $\mathrm{N}$ & $\mathrm{P}$ & $\mathrm{K}$ & $\mathrm{Ca}$ & $\mathrm{Mg}$ \\
\hline & & & \multicolumn{5}{|c|}{ Boot stage (summer) } \\
\hline \multirow[t]{4}{*}{ Two cuts } & 0 & 0 & 9.5 & 1.53 & 12.7 & 3.7 & 3.4 \\
\hline & 0 & 68 & 9.1 & 1.65 & 13.7 & 3.4 & 3.4 \\
\hline & 135 & 0 & 12.9 & 1.56 & 12.7 & 4.6 & 4.1 \\
\hline & 135 & 68 & 11.8 & 1.67 & 14.3 & 3.9 & 4.4 \\
\hline \multirow[t]{2}{*}{$\operatorname{LSD}_{(0.05)}$} & & & 1.4 & 0.12 & 1.3 & 0.5 & 0.3 \\
\hline & & & \multicolumn{5}{|c|}{ Regrowth harvested after frost (winter) } \\
\hline \multirow[t]{4}{*}{ Two cuts } & 0 & 0 & 13.1 & 0.99 & 3.3 & 4.5 & 3.6 \\
\hline & 0 & 68 & 12.2 & 0.96 & 2.5 & 4.2 & 3.3 \\
\hline & 135 & 0 & 14.6 & 1.06 & 3.8 & 4.7 & 3.9 \\
\hline & 135 & 68 & 14.3 & 1.07 & 4.2 & 4.5 & 3.9 \\
\hline \multirow[t]{2}{*}{$\operatorname{LSD}_{(0.05)}$} & & & 1.8 & 0.12 & 1.2 & 0.5 & 0.6 \\
\hline & & & \multicolumn{5}{|c|}{ Summer/winter weighted average } \\
\hline \multirow[t]{4}{*}{ Two cuts ${ }^{\mathrm{a}}$} & 0 & 0 & 10.3 & 1.40 & 10.3 & 3.9 & 3.5 \\
\hline & 0 & 68 & 9.9 & 1.48 & 10.9 & 3.7 & 3.4 \\
\hline & 135 & 0 & 13.1 & 1.44 & 10.7 & 4.6 & 4.1 \\
\hline & 135 & 68 & 12.3 & 1.53 & 11.7 & 4.1 & 4.3 \\
\hline \multirow[t]{2}{*}{$\operatorname{LSD}_{(0.05)}$} & & & 2.1 & 0.13 & 1.0 & 0.8 & 0.3 \\
\hline & & & \multicolumn{5}{|c|}{ After frost (winter) } \\
\hline \multirow[t]{4}{*}{ One cut } & 0 & 0 & 7.8 & 0.94 & 2.9 & 2.9 & 3.2 \\
\hline & 0 & 68 & 6.7 & 0.93 & 2.4 & 2.8 & 3.2 \\
\hline & 135 & 0 & 9.5 & 1.04 & 2.4 & 2.9 & 3.8 \\
\hline & 135 & 68 & 9.1 & 1.12 & 2.9 & 3.1 & 3.7 \\
\hline $\operatorname{LSD}_{(0.05)}$ & & & 1.4 & 0.13 & 0.6 & 0.4 & 0.5 \\
\hline
\end{tabular}


unfertilized plots. Nitrogen fertilizer increased nutrient concentration for all nutrients, except $\mathrm{Ca}$; however, $\mathrm{K}$ fertilizer did not affect nutrient ( $\mathrm{N}, \mathrm{P}, \mathrm{K}, \mathrm{Ca}$, and $\mathrm{Mg}$ ) concentration.

\section{Nutrient Removal}

Nitrogen and Ca removal was affected by $\mathrm{N}$ fertilizer and harvest timing while $\mathrm{P}, \mathrm{K}$, and $\mathrm{Mg}$ removal was affected harvest timing by $\mathrm{N}$ fertilizer and harvest timing by $\mathrm{K}$ fertilizer treatment interactions. The two-cut system removed greater amounts of N (67\%), P (74 \%), K (392\%), Ca (65\%), and $\mathrm{Mg}(32 \%)$ than the one-cut system (Table 3). In the one-cut system, applying either $\mathrm{N}$ or $\mathrm{K}$ alone generally did not affect nutrient removal when compared to the unfertilized check; however, switchgrass fertilized with both $\mathrm{N}$ and $\mathrm{K}$ fertilizer removed 37-48, 31-40, and 26-35\% greater $\mathrm{N}, \mathrm{P}$, and $\mathrm{Mg}$, respectively, when compared to switchgrass removal in the non-N fertilizer treatments.

During the boot stage harvest in summer for the two-cut system, $\mathrm{K}$ fertilizer generally did not affect nutrient removal by switchgrass receiving no $\mathrm{N}$ fertilizer. Compared to switchgrass receiving no fertilizer, $\mathrm{N}$ fertilized switchgrass removed greater amounts of $\mathrm{N}(44 \%), \mathrm{Ca}(12 \%)$, and $\mathrm{Mg}$ (28\%). Switchgrass receiving both $\mathrm{K}$ and $\mathrm{N}$ fertilizer removed $40 \%$ greater nutrients compared to switchgrass receiving only $\mathrm{K}$ fertilizer. For regrowth harvest in winter, $\mathrm{N}$ and $\mathrm{K}$ fertilized switchgrass removed greater amounts of nutrients than switchgrass receiving either fertilizer or no fertilizer. Because harvested biomass and its nutrient concentration were greater in summer than in that of regrowth harvest in the winter, nutrient removal was much greater in summer.

\section{Discussion}

The biomass production in summer (boot stage) when switchgrass began reproductive phase was $90 \%$ of one-cut harvest in winter, a fraction comparable to those found by others $[7,22,27]$. Low additional biomass after this time
Table 3 Amount of nutrients removed by biomass in summer and winter harvested biomass as affected by harvest system, $\mathrm{N}$ and $\mathrm{K}$ fertilizer application

\begin{tabular}{|c|c|c|c|c|c|c|c|}
\hline \multirow[t]{2}{*}{ Harvest system } & \multirow[t]{2}{*}{$\mathrm{N}$ rate } & \multirow[t]{2}{*}{$\mathrm{K}$ rate } & \multicolumn{5}{|c|}{ Nutrient removal $\left(\mathrm{kgha}^{-1}\right)$} \\
\hline & & & $\mathrm{N}$ & $\mathrm{P}$ & $\mathrm{K}$ & $\mathrm{C} \mathrm{a}$ & $\mathrm{Mg}$ \\
\hline & & & \multicolumn{5}{|c|}{ Boot stage (summer) } \\
\hline \multirow[t]{4}{*}{ Two cuts } & 0 & 0 & 109 & 17.6 & 146 & 43 & 39 \\
\hline & 0 & 68 & 95 & 17.2 & 142 & 35 & 35 \\
\hline & 135 & 0 & 157 & 19.0 & 155 & 56 & 50 \\
\hline & 135 & 68 & 171 & 24.2 & 207 & 57 & 64 \\
\hline \multirow[t]{2}{*}{$\operatorname{LSD}_{(0.05)}$} & & & 20 & 2.2 & 24 & 10 & 8 \\
\hline & & & \multicolumn{5}{|c|}{ Regrowth harvested after frost (winter) } \\
\hline \multirow[t]{4}{*}{ Two cuts } & 0 & 0 & 47 & 3.6 & 12 & 16 & 13 \\
\hline & 0 & 68 & 45 & 3.6 & 9 & 16 & 12 \\
\hline & 135 & 0 & 55 & 4.0 & 14 & 18 & 15 \\
\hline & 135 & 68 & 67 & 5.0 & 20 & 21 & 18 \\
\hline \multirow[t]{2}{*}{$\operatorname{LSD}_{(0.05)}$} & & & 14 & 0.8 & 6 & 4 & 3 \\
\hline & & & Total & & & & \\
\hline \multirow[t]{4}{*}{ One cut } & 0 & 0 & 97 & 11.7 & 36 & 36 & 40 \\
\hline & 0 & 68 & 90 & 12.5 & 32 & 38 & 43 \\
\hline & 135 & 0 & 127 & 13.9 & 32 & 39 & 51 \\
\hline & 135 & 68 & 133 & 16.4 & 42 & 45 & 54 \\
\hline \multirow[t]{4}{*}{ Two cuts } & 0 & 0 & 156 & 21.2 & 158 & 59 & 52 \\
\hline & 0 & 68 & 140 & 20.7 & 152 & 51 & 48 \\
\hline & 135 & 0 & 213 & 23.1 & 169 & 74 & 65 \\
\hline & 135 & 68 & 238 & 29.2 & 227 & 78 & 82 \\
\hline \multirow[t]{2}{*}{$\operatorname{LSD}_{(0.05)}$} & & & 37 & 2.3 & 21 & 14 & 9 \\
\hline & & & \multicolumn{5}{|c|}{ Harvest system mean } \\
\hline Two cuts (summer) & - & - & 133 & 19.5 & 163 & 48 & 47 \\
\hline Two cuts (winter) & - & - & 54 & 4.1 & 14 & 18 & 15 \\
\hline One cut & - & - & 112 & 13.6 & 36 & 40 & 47 \\
\hline $\operatorname{LSD}_{(0.05)}$ & & & 11 & 1.1 & 10 & 8 & 4 \\
\hline
\end{tabular}


may have been due to allocation of resources away from vegetative towards reproductive development, and thus diminished reserves available for regrowth. In addition, lower rainfall during late summer after harvest, likely contributed to the reduction in biomass production in the regrowth. The greater total annual biomass from the two-cut systems is due to additional growth that occurred after harvest in July, which is similar to initial findings of Monti et al [27]. Unlike the one-cut system where the plant canopy likely hindered light penetration and reduced growth of crown buds, harvesting in July exposed the buds to sunlight and stimulated growth. Before onset of killing frost, total growth of new tillers from crown buds that breaks after summer cut would be greater than that achieved in an uncut canopy. Based on results of this study, the two-cut system maximized total switchgrass biomass yield, although this system would require greater nutrient inputs.

The effects of harvest system and $\mathrm{K}$ fertilizer rate on biomass yield and nutrient removal rates of switchgrass were evaluated under no-N fertilizer or adequate $(135 \mathrm{kgN}$ $\mathrm{ha}^{-1}$ ) $\mathrm{N}$ fertilizer. Greater nutrient concentration in the summer harvest compared to winter is due to fact that switchgrass was harvested at the start of reproductive stage. In the one-cut per year system, switchgrass nutrient remobilization may have started earlier after physiological maturity, and hence, the relatively lesser nutrient concentrations than that occurring in regrowth biomass. However, compared to the summer harvest, the greater nutrient levels in the regrowth may be due to the relatively high leaf to stem ratio for the regrowth compared to summer-harvested material.

The greater nutrient removal by the two-cut system was a result of the great amount of nutrient removed during the summer harvest when biomass nutrient concentrations were greater. Within the one-cut only system, switchgrass started senescence after flowering and nutrients were remobilized to below-ground storage reserves. While remobilization of nutrients from senescing organs to other parts of the plants have been reported in studies on other plants [29-32], it has been reported that nutrient concentration in switchgrass material in autumn is less than in the winter [7, 13, 21] because in the autumn, the plant is initiating senescence while in winter, the above-ground portion is dead. Therefore, by the time of frost kill at end of November, significant amounts of nutrient will have been removed from the aboveto below-ground structures. In addition, nutrients like K, which are easily leached [24], may continue being lost as switchgrass senesces in the field. This could explain the more than fourfold reduction in biomass $\mathrm{K}$ concentration in winter-harvested material compared to that in summer. Remobilization and loss of nutrients explains the lesser removal rates observed in one-cut per year harvest system. The increase in $\mathrm{N}, \mathrm{P}, \mathrm{K}$, and $\mathrm{Mg}$ removal rates with $\mathrm{N}$ fertilizer was a result of both the increase in biomass and nutrient concentrations with $\mathrm{N}$ fertilization. Due to the greater nutrient removal of the two-cut system, the one-cut system may be more sustainable.

\section{Conclusion}

Based on these results, there was no yield advantage to harvesting twice during the season, combined with fact that the two-cut system removed greater amounts of nutrients, which would require greater inputs. Therefore a single-cut harvest after frost would be recommended for switchgrass biofuel production. In soils with low plant-available $\mathrm{K}$, there was no switchgrass yield response to $\mathrm{K}$ fertilizer when applied alone, nor was there a yield response to $\mathrm{N}$ fertilizer when applied alone. However, there was a yield response to $\mathrm{N}$ and $\mathrm{K}$ when applied together, indicating that for maximum biofuel production, proper nutrient management $(\mathrm{N}, \mathrm{P}$, and $\mathrm{K}$ ) is required for switchgrass that is touted as a low input crop, even for a single cut after frost harvest system, that recycles much of its nutrients.

Open Access This article is distributed under the terms of the Creative Commons Attribution License which permits any use, distribution, and reproduction in any medium, provided the original author(s) and the source are credited.

\section{References}

1. Parrish DJ, Fike JH (2005) The biology and agronomy of switchgrass for biofuels. Crit Rev Plant Sci 24(5-6):423-459

2. McLaughlin SB, Kszos LA (2005) Development of switchgrass (Panicum virgatum) as a bioenergy feedstock in the United States. Biomass Bioenerg 28:515-535

3. Samson R, Sudhagar M, Boddey R, Sokhansanj S, Quesada D, Urquiaga $S$ et al (2005) The potential of $C 4$ perennial grasses for developing a global bioheat industry. Crit Rev Plant Sci 24:461-495

4. Sanderson MA, Read JC, Reed RL (1999) Harvest management of switchgrass for biomass feedstock and forage production. Agron J 91:5-10

5. Muir JP, Sanderson MA, Ocumpaugh WR, Jones RM, Reed RL (2001) Biomass production of Alamo switchgrass in response to nitrogen, phosphorus, and row spacing. Agron J 93:896-901

6. Vogel KP, Brejda JJ, Walter DT, Buxton DR (2002) Switchgrass biomass production in the Midwest USA: harvest and nitrogen management. Agron J 94:413-420

7. Guretzky JA, Biermacher JT, Cook BJ, Kering MK, Mosali J (2011) Switchgrass for forage and bioenergy: harvest and nitrogen rate effects on biomass yields and nutrient composition. Plant Soil 339:69-81

8. Rehm GW, Sorensen RC, Moline WJ (1976) Time and rate of fertilizer application for seeded warm season and bluegrass pastures. I. Yield and botanical composition. Agron J 68:759-764

9. Taylor RW, Allison DW (1982) Response of 3 warm season grasses to varying fertility levels on 5 soils. Can J Plant Sci 62:657-666 
10. Rehm GW (1984) Yield and quality of warm season grass mixture treated with N, P, and atrazine. Agron J 76:731-734

11. McKenna JR, Wolf DD (1990) No-till switchgrass establishment as affected by limestone, phosphorus and carbofuran. J Prod Agric 3:475-479

12. Brejda JJ, Yocom DH, Moser LE, Waller SS (1993) Dependence of 3 Nebraska Sandhill warm-season grasses on vesicular-arbuscular mycorrhiza. J Range Manage 46:14-20

13. Kering MK, Biermacher JT, Butler TJ, Mosali J, Guretzky JA (2012) Biomass yield and nutrient responses of switchgrass to phosphorus fertilization. Bioenergy Res 5:71-78

14. Marschner P (2011) Mineral nutrition of higher plants, 3rd edn. Academic, London, pp 135-178

15. Snyder CS, Leep RH (2007) Fertilization. In: Barnes RF, Nelson CJ, Moore KJ, Collins M (eds) Forages the science of grassland agriculture II. Blackwell, Ames, pp 355-377

16. Brar MS, Bijay-Singh, Bansal SK, Srinivasarao Ch (2011) Role of potassium nutrition in nitrogen use efficiency in cereals. Research Findings: e-ifc No. 29. International Potash Institute http://www. ipipotash.org/en/eifc/2011/29/5. Accessed: 10 March 2011

17. Seay R, Slaton NA (2008) Bermudagrass yield response to nitrogen and potassium fertilization in northwest Arkansas. Forage and Grazinglands. doi:10.1094/FG-2008-0818-01-RS

18. Nelson LR, Keisling TC, Roquette MJR (1983) Potassium rates and sources for coastal Bermudagrass Cynodon dactylon. Soil Sci Soc Amer 47:963-966

19. Smith D (1979) Fertilization of switchgrass in the greenhouse with various levels of nitrogen and potassium. Agron J 71:149-150

20. Koelling MR, Kucera CL (1965) Dry matter losses and mineral leaching in bluestem standing crop and litter. Ecology 46:529-532

21. Yang JD, Worley E, Wang MY, DE Lahner S, Saha M, Udvardi M (2009) Natural variation for nutrient use and remobilization efficiencies in switchgrass. Bioenergy Res 4:257-266

22. Fike JH, Parrish DJ, Wolf DD, Balasko JA, Green JT Jr, Rasnake $M$ et al (2006) Switchgrass production for the upper southeastern USA: influence of cultivar and cutting frequency on biomass yields. Biomass Bioenerg 30:207-213

23. Reynolds JH, Walker CL, Kirchner MJ (2000) Nitrogen removal in switchgrass under two harvest systems. Biomass Bioenerg 19:281-286

24. Fixen PE (2007) Potential biofuels influence on nutrient use and removal in the US. Better Crops 91:12-14

25. Adler PR, Sanderson MA, Boateng AA, Weimer PJ, Jung HG (2006) Biomass yield and biofuel quality of switchgrass harvested in fall or spring. Agron J 98:1518-1525

26. Goel K, Eisner R, Sherson G, Radiotis T, Li J (2000) Switchgrass: a potential pulp fibre source. Pulp \& Paper-Canada 101:41-45

27. Monti A, Bezzi G, Pritoni G, Venturi G (2008) Long-term productivity of lowland switchgrass cytotypes as affected by cutting frequency. Bioresource Technol 99:7425-7432

28. Zhang H, Raun B (2006) Oklahoma soil fertility handbook, 6th edn. Department of Plant and Soil Sciences, Stillwater

29. Batten GD, Wardlaw IF (1987) Senescence and grain development in wheat plants grown with contrasting phosphorous regimes. Aust J Plant Physiol 14:253-265

30. Lynch J, White JW (1992) Shoot nitrogen dynamics in the tropical common bean. Crop Sci 32:392-397

31. Sánchez-Alonso F, Lachica M (1987) Seasonal trends in the mineral content of sweet cherry leaves. Commun Soil Sci Plant Anal $18: 17-29$

32. Milla R, Castro-Díez P, Maestro-Martínez M, Montserrat-Marti G (2005) Relationship between phenology and remobilization of nitrogen, phosphorus and potassium in branches of eight Mediterranean evergreens. New Phytologist 168:167-178 